\title{
Effects of Pterocaulon polystachyum DC. (Asteraceae) on onion (Allium cepa) root-tip cells
}

\author{
Michelle Frainer Knoll, Antonio Carlos Ferreira da Silva, Thais Scotti do Canto-Dorow \\ and Solange Bosio Tedesco
}

Departamento de Biologia, Universidade Federal de Santa Maria, Santa Maria, RS, Brazil.

\begin{abstract}
In Brazil leaf infusions of the plant Pterocaulon polystachyum DC (Asteraceae) are used to treat digestive problems. We used plants from six $P$. polystachyum populations to prepare fresh aqueous leaf infusions at the concentration normally used in Brazil $\left(2.5 \mathrm{~g} \mathrm{~L}^{-1}\right)$ and at twice $\left(5 \mathrm{~g} \mathrm{~L}^{-1}\right)$ and four times $\left(10 \mathrm{~g} \mathrm{~L}^{-1}\right)$ this concentration. We rooted onion bulbs in a water control or one of the infusions for $24 \mathrm{~h}$ and used the in vivo onion (Allium cepa) root-tip cell test to investigate the potential mutagenicity of the infusions by calculating the mitotic index for the control and the experimental treatments and comparing them using the Chi-squared test $\left(\chi^{2}, p=0.05\right)$. There was a highly significant decrease in the mitotic index of root-tip cells treated with infusion as compared to those exposed to water only. These results indicate that $P$. polystachyum infusions present cytotoxic and anti-proliferative activity and therefore have therapeutic potential.
\end{abstract}

Key words: medicinal plants, mutagenicity, onion (Allium cepa) test, Pterocaulon polystachyum.

Received: June 14, 2005; Acepted: November 11, 2005.

\section{Introduction}

Medicinal plants are used in both the pharmaceutical industry and as alternative non-prescription medicines, although systematic investigations of the therapeutic potential of such species are often lacking. Plant biodiversity is extensive but only $15 \%$ to $17 \%$ of known plant species have been systematically studied for their medicinal properties (Simões et al., 2001).

In developing and non-industrialized countries, including Brazil, plant infusions are commonly used to treat a wide range of diseases (Teixeira et al., 2003). However, it has also been pointed out that while some medicinal plants may suppress the effects of mutagens others may contain toxic substances or provoke mutagenic effects (Vicentini et al., 2001) so mutagenicity testing is required before the use of a specific medicinal plant can be endorsed.

Brazil has one of the highest levels of biodiversity and potential genetic resources in terms of medicinal plants which can serve as primary sources for the manufacture of synthetic pharmaceuticals. One of the many plants used as popular non-prescription medicines In Brazil is Pterocaulon polystachyum ('quitoco' in Portuguese), which is found in southern Brazil, Paraguay, northeastern

Send correspondence to Solange Bosio Tedesco. Departamento de Biologia, Centro de Ciências Naturais e Exatas, Universidade Federal de Santa Maria, Av. Roraima 1000, Cidade Universitária, Camobi, 97105900 Santa Maria, RS, Brazil. E-mail: stedesco@ smail.ufsm.br.
Argentina and Uruguay (Burkart, 1974) and is widely distributed in the southern Brazilian state of Rio Grande do Sul where infusions of its leaves are used in the treatment of various digestive disorders (Lopes, 1995), for the direct application to injuries and to repel insects (Zardini, 1983).

The effects of mutagens on eukaryotic nuclei can be assessed cytologically by observing inhibition of cell growth or division, interruption of metaphase or the induction of numerical and structural chromosomal aberrations and changes among sister and other chromatids (Vieira and Vicentini, 1997).

Cytotoxicity and environmental pollution (ElShahaby et al., 2003) have been assessed by the in vivo onion (Allium cepa) root-tip cell test, which is known to give similar results to in vitro animal cytotoxicity tests (Teixeira et al., 2003; Vicentini et al., 2001, Chauhan et al., 1999). Onion root-tip cytotoxicity tests are based on the analysis of various parameters including atypical nucleolus patterns (e.g. heteromorphic pairing of nucleoli) and the appearance of micronuclei as a consequence of disordered mitosis and chromosomal breakdown (Grover and Kaur, 1999).

It is known (Vera, 2001) that $P$. polystachyum leaves contain compounds such as coumarin with known cytotoxic activity (Mongelli et al., 2000; Riveiro et al., 2004). The aim of our study was to use the in vivo onion (Allium сера) root-tip cell test to investigate the cytotoxic and mutagenic potential of leaf infusions prepared from various $P$. polystachyum populations. 


\section{Material and Methods}

\section{Plant material}

The experiments were conducted at the Plant Cytogenetics Laboratory of the Federal University of Santa Maria (Universidade Federal de Santa Maria, UFSM), Rio Grande do Sul (RS) state, Brazil. We collected plants from different Pterocaulon polystachyum (Asteraceae) populations from six sites (populations P1 to P6) in Rio Grande do Sul: Boca do Monte, Santa Maria (P1); Paraíso do Sul, Santa Maria (P2); São Sepé road BR 392 (P3); São Pedro road intersection (P4); São Sepé (P5) Camobi road BR287, Santa Maria (P6). Voucher samples from each population were deposited in the UFSM herbarium.

\section{Infusion preparation and onion root-tip cell test.}

Fresh young leaves from the branches of $P$. polystachyum grown in your natural habitat were placed in boiling water for five minutes and the extracts filtered through filter-paper and cooled to room temperature. The infusions were prepared at the concentration normally used in Brazil $\left(2.5 \mathrm{~g} \mathrm{~L}^{-1}\right)$ and at twice $\left(5 \mathrm{~g} \mathrm{~L}^{-1}\right)$ and four times $\left(10 \mathrm{~g} \mathrm{~L}^{-1}\right)$ this concentration.

For the onion root-tip cell test we used 18 Allium cepa bulbs divided into three groups (one for each infusion concentration) of six onion bulbs for each $P$. polystachyum population. For each infusion, all bulbs were rooted in water for three days after which four bulbs were placed in the infusion for $24 \mathrm{~h}$, the remaining two bulbs being left in the water where they had rooted for a further $24 \mathrm{~h}$ to act as controls which had received no infusion. After $24 \mathrm{~h}$ the roottips, measuring from five to ten millimeters, from both the control and experimental bulbs were collected and fixed in $3: 1(\mathrm{v}: \mathrm{v})$ ethanol-acetic acid for $24 \mathrm{~h}$ before being placed in $70 \%(\mathrm{v} / \mathrm{v})$ aqueous ethanol and refrigerated until needed. An average of five slides was made for each bulb using five root-tips which were hydrolyzed in $1 \mathrm{~N}$ hydrochloric acid for five minutes and washed in distilled water, the fragmented meristematic region being stained with $2 \%(\mathrm{w} / \mathrm{v})$ acetic orcein. Five fields were assessed for each slide and the number of interphase, prophase, metaphase, anaphase and telophase cells recorded using bright-field optical microscope with a $40 \mathrm{X}$ objective. For each $P$. polystachyum population we assessed 6000 cells for each treatment and for the controls and the mean values for the different cellcycle phases and the mitotic index (MI) was calculated. Statistical analysis was performed using the Chi-squared $\left(\chi^{2}\right)$ test at $\mathrm{p}=0.05$.

\section{Results}

The number of interphase, prophase, metaphase, anaphase and telophase cells are shown in Table 1. For the $10 \mathrm{~g} \mathrm{~L}^{-1}$ infusion made from $P$. polystachyum population 1 leaves the number of anaphase cells was low and there were no prophase and metaphase or telophase cells, while for the $10 \mathrm{~g} \mathrm{~L}^{-1}$ population 2 infusion there were no telophase cells.

Table 2 shows the number of interphase and dividing cells along with the mean mitotic index (MI). For population 1 infusions the control mitotic index (7.5\%) was significantly higher than for any of the extracts and these also differed significantly from each other with the lowest mitotic index being $0.03 \%$ for the $10 \mathrm{~g} \mathrm{~L}^{-1}$ infusion, similar results also occurring with population 2 . For population 3 infusions and the control the mitotic index ranged from $7 \%$

Table 1 - Number of onion root-tip cells in different phases of the cell cycle. The onions were placed for $24 \mathrm{~h}$ in water (control) or aqueous infusions of $2.5,5$ or $10 \mathrm{~g}$ per litre of fresh leaves from six different Pterocaulon polystachyum populations.

\begin{tabular}{|c|c|c|c|c|c|}
\hline \multirow[t]{2}{*}{ Pop } & \multicolumn{5}{|c|}{ Number of cells in different phases of the cell cycle } \\
\hline & Interphase & Prophase & Metaphase & Anaphase & Telophase \\
\hline \multicolumn{6}{|c|}{ Population 1} \\
\hline Control & 5549 & 125 & 81 & 127 & 118 \\
\hline 2.5 & 5725 & 72 & 52 & 61 & 90 \\
\hline 5 & 5952 & 18 & 8 & 10 & 12 \\
\hline 10 & 5998 & 0 & 0 & 2 & 0 \\
\hline \multicolumn{6}{|c|}{ Population 2} \\
\hline Control & 5361 & 1.004 & 416 & 581 & 588 \\
\hline 2.5 & 5592 & 178 & 78 & 75 & 77 \\
\hline 5 & 5844 & 52 & 24 & 43 & 37 \\
\hline 10 & 5978 & 11 & 7 & 4 & 0 \\
\hline \multicolumn{6}{|c|}{ Population 3} \\
\hline Control & 5580 & 161 & 78 & 60 & 121 \\
\hline 2.5 & 5690 & 199 & 68 & 87 & 97 \\
\hline 5 & 5590 & 206 & 56 & 59 & 89 \\
\hline 10 & 5549 & 129 & 50 & 42 & 89 \\
\hline \multicolumn{6}{|c|}{ Population 4} \\
\hline Control & 5663 & 80 & 90 & 57 & 110 \\
\hline 2.5 & 5714 & 107 & 40 & 27 & 61 \\
\hline 5 & 5680 & 128 & 66 & 32 & 94 \\
\hline 10 & 5765 & 118 & 48 & 26 & 94 \\
\hline \multicolumn{6}{|c|}{ Population 5} \\
\hline Control & 5546 & 110 & 116 & 75 & 153 \\
\hline 2.5 & 5829 & 84 & 53 & 44 & 91 \\
\hline 5 & 5695 & 113 & 63 & 43 & 86 \\
\hline 10 & 5728 & 52 & 42 & 34 & 43 \\
\hline \multicolumn{6}{|c|}{ Population 6} \\
\hline Control & 5602 & 150 & 68 & 72 & 102 \\
\hline 2.5 & 5813 & 100 & 70 & 42 & 79 \\
\hline 5 & 5839 & 35 & 49 & 21 & 56 \\
\hline 10 & 5709 & 34 & 50 & 34 & 69 \\
\hline
\end{tabular}

Pop: Pterocaulon polystachyum population and grams of leaves per litre of infusion. 
Table 2 - Number of interphase and dividing cells and the mitotic index of onion root-tip cells. The onions were placed for $24 \mathrm{~h}$ in water (control) or aqueous infusions of $2.5,5$ or $10 \mathrm{~g}$ per litre of fresh leaves from six different Pterocaulon polystachyum populations. The total number of cells analyzed for each treatment was 6000 .

\begin{tabular}{lccc}
\hline Pop & \multicolumn{2}{c}{ Number of cells } & \\
\cline { 2 - 4 } & $\begin{array}{c}\text { Interphase } \\
\text { cells }\end{array}$ & $\begin{array}{c}\text { Dividing } \\
\text { cells }\end{array}$ & $\begin{array}{c}\text { Mitotic index } \\
(\%)\end{array}$ \\
\hline Population 1 & & & \\
Control & 5549 & 451 & $7.5 \mathrm{a}$ \\
2.5 & 5725 & 275 & $5.05 \mathrm{~b}$ \\
5 & 5952 & 48 & $0.8 \mathrm{c}$ \\
10 & 5998 & 2 & $0.03 \mathrm{~d}$ \\
\hline Population 2 & & & $10.64 \mathrm{a}$ \\
Control & 5361 & 639 & $6.8 \mathrm{~b}$ \\
2.5 & 5592 & 408 & $2.6 \mathrm{c}$ \\
5 & 5844 & 156 & $0.4 \mathrm{~d}$ \\
10 & 5978 & 22 & \\
\hline
\end{tabular}

Population 3

\begin{tabular}{llll} 
Control & 5580 & 420 & $7 \mathrm{a}$ \\
2.5 & 5549 & 451 & $7.5 \mathrm{a}$ \\
5 & 5590 & 410 & $6.8 \mathrm{a}$ \\
10 & 5690 & 310 & $5.16 \mathrm{~b}$ \\
\hline
\end{tabular}

Population 4

\begin{tabular}{llll} 
Control & 5663 & 337 & $5.6 \mathrm{a}$ \\
2.5 & 5714 & 286 & $4.7 \mathrm{ab}$ \\
5 & 5680 & 320 & $5.3 \mathrm{a}$ \\
10 & 5765 & 235 & $4 \mathrm{~b}$ \\
\hline
\end{tabular}

Population 5

\begin{tabular}{llll} 
Control & 5546 & 454 & $7.5 \mathrm{a}$ \\
2.5 & 5728 & 272 & $4.5 \mathrm{~b}$ \\
5 & 5695 & 305 & $5 \mathrm{~b}$ \\
10 & 5829 & 171 & $2.8 \mathrm{bc}$ \\
\hline
\end{tabular}

Population 6

\begin{tabular}{llll} 
Control & 5602 & 392 & $6.6 \mathrm{a}$ \\
2.5 & 5709 & 291 & $4.8 \mathrm{~b}$ \\
5 & 5839 & 161 & $2.6 \mathrm{c}$ \\
10 & 5813 & 187 & $3.1 \mathrm{c}$ \\
\hline
\end{tabular}

Pop: Pterocaulon polystachyum population and grams of leaves per litre of infusion.

Means followed by the same letter do not differ significantly by the chi-square test at $\mathrm{p}=05$.

to about $5 \%$ and decreased as the concentration of the infusion increased, but in this case there was no significant difference between the control and the $2.5 \mathrm{~g} \mathrm{~L}^{-1}$ infusion $\left(\chi^{2}=1.19, \alpha=0.05\right)$ and between the $2.5 \mathrm{~g} \mathrm{~L}^{-1}$ and $5 \mathrm{~g} \mathrm{~L}^{-1}$ infusions $\left(\chi^{2}=2.1, \alpha=0.05\right)$. The mitotic index for the population 4 infusions and the control ranged from $5.6 \%$ to $4 \%$ but there was no apparent relationship between mitotic index and infusion concentration, although there was a significant difference between the control group and the $10 \mathrm{~g} \mathrm{~L}^{-1}$ infusion for which the mitotic index was about $4 \%$ $\left(\chi^{2}=19.1, \alpha=0.05\right)$. For this population, as with population 3, the mitotic indices for the $2.5 \mathrm{~g} \mathrm{~L}^{-1}$ and $5 \mathrm{~g} \mathrm{~L}^{-1}$ infusions did not differ $\left(\chi^{2}=2.0, \alpha=0.05\right)$. For population P5 infusions and control the mitotic index ranged from $7.5 \%$ to $2.8 \%$ and the mitotic index for the control group differed significantly from that of all the treatments, but again the $2.5 \mathrm{~g} \mathrm{~L}^{-1}$ and $5 \mathrm{~g} \mathrm{~L}^{-1}$ infusions did not differ between themselves $\left(\chi^{2}=1.97, \alpha=0.05\right)$. The mitotic index of population 6 infusions and control ranged from $6.6 \%$ to $2.6 \%$, with the mitotic index values for the control group being significantly different from those for all the infusions, although in this case there was no significant difference between the values for the $10 \mathrm{~g} \mathrm{~L}^{-1}$ and $5 \mathrm{~g} \mathrm{~L}^{-1}$ infusions $\left(\chi^{2}=2.0, \alpha=0.05\right)$.

\section{Discussion}

Our results show that the higher the $10 \mathrm{~g} \mathrm{~L}^{-1} P$. polystachyum infusions produced the greatest inhibition of onion root-tip cell division (Table 1) and decreased mitotic index (Table 2) but there was no statistically significant intra or interpopulational variability for the $P$. polystachyum populations from different sites in regard to their cytotoxic effects.

Decreased mitotic index caused by P. polystachyum infusions have previously been reported by Mongelli et al. (1999) who studied Argentinean populations of this plant which have been used to treat cancers, these authors having demonstrated that $P$. polystachyum contains compounds which interact with the DNA. Our results regarding the cytotoxic activity of $P$. polystachyum support the work of Mongelli et al. (1999) and Riveiro et al. (2004) who have attributed these effects to the presence of coumarins.

Camparoto et al. (2002) have shown that Maytenus ilicifolia and Bauhinia candicans can cause decreased cell division in both onion root-tip and rat bone-marrow cells and decreased mitotic index in onion root-tip cells.

Riveiro et al. (2004) have reported that $P$. polystachyum extracts have antiproliferative and differential activities on human leukemic cells, indicating that such extracts may have therapeutic potential in the treatment of leukemia.

Our results not only support the antiproliferative and cytotoxic activity of $P$. polystachyum infusions but also show that at the concentrations studied there were no mutagenic effects on in vivo onion root-tip cells as witnessed by the fact that despite the large number of cells assessed there were no visible chromosome aberrations in either the treated or control cells.

Taken together our results indicate that not only is the onion root-tip test useful in assessing infusions prepared from different $P$. polystachyum populations but that such 
infusions have cytotoxic and anti activities and may have potential for the therapeutic inhibition of the cell cycle in eukaryotic organisms, although further studies will be necessary to establish its use as an antimutagenic agent for use in the treatment of humans with proliferative diseases.

\section{Acknowledgments}

We are grateful Profa Dra. Maria Rosa Chitolina Schetinger of the Federal University of Santa Maria (Universidade Federal de Santa Maria) for a critical reading of the manuscript.

\section{References}

Burkart AF (1974) Flora Ilustrada de Entre Rios (Argentina). Coleccion Cientifica del I.N.T.A. v. 6. I.N.T.A., Buenos Aires, $554 \mathrm{pp}$.

Camparoto ML, Teixeira RO, Mantovani MS and Vicentini VEP (2002) Effects of Maytenus ilicifolia Mart. and Bauhinia candicans Benth infusions on onion root-tip and rat bonemarrow cells. Genet Mol Biol 25:85-89.

Chauhan LKS, Saxena PN and Gupta S K (1999) Cytogenetic effects of cypermethrin and fenvalerate on the root meristem cells of Allium cepa. Environmental and Experimental Botany 42:181-189.

Lopes AMV (1995) Plantas Usadas na Medicina Popular do Rio Grande do Sul. Caderno Técnico. Imprensa Universitária, Santa Maria, 74 pp.

El-Shahaby AO, Abdel Migid HM, Soliman MI and Mashaly IA (2003) Genotoxicity screening of industrial wastewater using the Allium cepa chromosome aberration assay. Pakistan J Biol Sci 6:23-28.
Grover IS and Kaur S (1999) Genotoxicity of wastewater samples from sewage and industrial effluent detected micronucleus assays. Mutation Res 426:183-188.

Mongelli E, Coussio J and Ciccia G (1999) Medicinal species of the Solanaceae family: Primary screening of cytotoxicity. Acta Horticulturae 501:177-179.

Mongelli E, Pampuro S, Coussio J, Salomon H and Ciccia G (2000) Cytotoxic and DNA interaction activities of extracts from medicinal plants used in Argentina. J Ethnopharmacol 71:145-151.

Riveiro O (2004) Induction of cell differentiation in human leukemia U-937 cells by 5-oxygenated-6,7-methylenedioxycoumarins from Pterocaulon polystachyum. Cancer Letters 210:179-188.

Simões CMO, Schenkel EP, Gossmann G, Mello JCP, Mentz LA and Petrovick PR (2001) Farmacognosia: Da Planta ao Medicamento. 3 edition. Editora da Universidade Federal do Rio Grande do Sul,Porto Alegre, 821 pp.

Teixeira RO, Camparoto ML, Mantovani MS and Vicentini VEP (2003) Assessment of two medicinal plants Psidium guajava L. and Achillea millefolium L., in in vitro and in vivo assays. Gen Mol Biol 26:551-555.

Vera N, Bandon A, Catalan CA, Gedris TE and Herz W (2001) New coumarins from Pterocaulon polystachyum. Planta Medica 67:674-677.

Vicentini VEP, Camparoto ML, Teixeira RO and Mantovani MS (2001) Averrhoa carambola L., Syzygium cumini (L.) Skeels and Cissus sicoydes L.: Medicinal herbal tea effects on vegetal and animal test systems. Acta Scientiarum 23:593-598.

Vieira D and Vicentini VEP (1997) Estudo do efeito mutagênico do floxacin em Allium cepa. Rev Brasil Genét (Supplement) 20:115-115.

Zardini EM (1983). Etnobotánica de Compuestas argentinas con especial referencia a seu uso farmacológico. Acta Farmacêutica Bonaerense 3:77-79.

Associate Editor: Marcelo Guerra 